\title{
The Consequences of the Lviv Pogrom on November 22-23, 1918, in Light of the Findings and ACtions of the Jewish Rescue COMMITTEE
}

\author{
Wacław Wierzbieniec \\ (iD) https://orcid.org/0000-0001-8830-9982 \\ (University of Rzeszow, Poland) \\ e-mail:wacwie@ur.edu.pl
}

Keywords: Jews, Lviv, pogrom, Jewish Rescue Committee, antisemitism, material damage, victims, material aid

\begin{abstract}
In the areas that became part of the Second Polish Republic, manifestations of antisemitism became more pronounced at the end of World War I and at the beginning of the interwar period. These manifestations often turned into acts of violence against Jews, as became apparent in many towns with Jewish populations. The Lviv pogrom on 22-23 November 1918 was particularly devastating. The Jewish Rescue Committee, established in Lviv at that time, was very active in providing help to the injured, determining the number of casualties and wounded, and in assessing the extent of material damage resulting from the robberies and acts of destruction, including arson. According to the findings of the Jewish Rescue Committee, 73 people died and 443 were wounded as a result of the pogrom. The estimated material damage amounted to $102,986,839 \mathrm{Kr},{ }^{1}$ with a total of 13,375 people affected. The actions taken by the Jewish Rescue Committee to help the victims were extremely important and effective, but they did not fully satisfy the existing social needs.
\end{abstract}

\section{Introduction}

Throughout history, the Jewish diaspora has often had to struggle with acts of violence committed against them. The phenomenon of violence against Jews, the Jewish pogroms, could be observed in Europe, especially in Central and Eastern Europe, Poland included. In Galicia, these violent acts were noticeable at the end of World War I and in the first few following years. ${ }^{2}$ Lviv, where the scale of anti-Jewish violence was the largest and extremely brutal, was one of the cities affected by pogroms at that time.

Lviv, the urban center of Galicia, was home to the largest concentration of Jews in the region. In the interwar period Lviv had the third largest population of Jews in the Second

\footnotetext{
1 Austro-Hungarian currency known as "korona" or "krone."

2 This subject matter is already covered by many valuable analyses and elaborations. In my current research I present the issue of violence towards the Jews after World War I in the following publications: Wierzbieniec 2004a: 13-14; Wierzbieniec 2004b: 573-580; Wierzbieniec 2005a: 199-212; Wierzbieniec 2005b: 589-612; Wierzbieniec 2019: 443-464.
} 
Polish Republic, after Warsaw and Lodz. Both before World War I and in the interwar period, the Jewish population of Lviv was the second largest group after the Poles, with third place taken by Ukrainians. According to the 1910 census, Lviv had a population of 206,113 inhabitants, out of which there were 105,469 Roman Catholics, mostly Poles; 57,387 Jews; and 39,314 Greek Catholics, who were mostly Ukrainians. Thus, Jews constituted $27.8 \%$ of the total population. ${ }^{3}$

The tragic Lviv pogrom took place on 22-23 November 1918, but signs of violence against Jews were still evident in the following days and months. The issues pertaining to the origin, process and the following consequences of these tragic events and the participation of Poles in the pogrom, including the Polish Army, began to arouse much controversy as early as in the end of November 1918. These controversies, both in the literature of memoirs and in scientific studies, continue to this day. ${ }^{4}$

In relation to the consequences of the great tragedy that was the Lviv pogrom, relatively little attention in historical literature has been paid to the activities of the Jewish Rescue Committee and its role in providing assistance to the victims, or to documenting the consequences of the pogrom. My aim with this article is to fill this gap, if only slightly.

The great importance and significance of the Jewish Rescue Committee, in comparison with the actions taken by Polish and foreign pogrom commissions, including the Henry Morgenthau Commission, ${ }^{5}$ was based on the very large scale of its activities and from the fact that it had, as an organ chosen by the Lviv Jews, the greatest potential to reach a large number of the victims. It was the victims, their trauma experienced during the pogrom, and the urgent need to help them that made the Committee's work meaningful and, at the same time, testified to its importance.

In the following considerations I focus on the origin, objectives, composition and structure of the Jewish Rescue Committee. I will point to selected reactions of Jewish circles to its appeals for help. I would like to draw attention to the scope and forms of assistance provided to victims in the first months after the November pogrom. I will also refer to the Committee's very important findings on the brutality of pogroms, the number of people killed, injured and robbed, and the extent and type of material damage.

\section{Origin, objectives, composition and structure of the Committee}

There was an urgent need to help the large number of victims of the pogrom. The amount of assistance that had to be given to the victims required a great deal of organizational effort and generosity. As a result of consultations between various Jewish

\footnotetext{
3 Drexler 1920: 14-18; Wierzbieniec 2000: 290.

4 Soon after the Lviv pogrom in November 1918, a very noteworthy book describing this issue, Der Lemberger Judenpogrom (November 1918-Jänner 1919), by J. Bendow, was published. It is frequently cited in many scientific elaborations. The last dozen or so years have provided valuable additional insights into the matter thanks to the work of American historian William W. Hagen: Hagen 2005: 124-147; Hagen 2018: 148-182. The most recent Polish sources referring to the pogrom include: Imiłowska-Duma 2017: 117-134; Zaporowski 2018: 465-472; Zaporowski 2019: 270-280; Markowski 2019: 325-339; Gauden 2019.

5 Engel 2004: 387-395; Urynowicz 2010: 70-79.
} 
groups, it was decided that it would be most appropriate to unite their efforts and act together for the benefit of the victims of the pogrom through a specially established organization. Consequently, on 29 November 1918, the Jewish Committee for Aid to the Victims of Riots and Robberies was established in Lviv (later known as the Jewish Rescue Committee). ${ }^{6}$ The Committee also became a representative of Lviv Jews before the civil and military authorities ${ }^{7}$ in relation to the November pogrom and its consequences, including the safety of Jews, which was threatened by further violence, although on a much smaller scale.

The Committee consisted of 50 members representing all the existing Jewish factions and political groups in Lviv. The structure of the Committee in the following months and years underwent changes due to the shifting social needs. From among its members, the Committee selected an Executive Department, Presidium, and units to deal with specific issues. In addition, there was a secretariat serving the Executive Department and the Presidium, as well as a central office serving people applying to the Committee.

The day-to-day work of the Committee was headed by the Presidium, headed by Dr Emil Parnas, who also served as Chairman of the Executive Department. The Presidium also included a number of other members: Dawid Rubenzahl as secretary, Dr Tobiasz Askenase, Dr Rafał Buber, Rabbi Leib Braude, Karol Einäugler, Wiktor Chajes, Rabbi Dr Samuel Guttmann, Dr Aleksander Hausmann, Salomon Herz, Dr Aleksander Mayer, Dr Józef Parnas, Dr Michał Ringel, Prof. Dr Mojżesz Schorr, Dr Dawid Schreiber, and Dr Ozyasz Wasser. Later on Dr Hausmann and Dr Ringel, who were taken hostage and deported from Lviv on 12 December 1918, were replaced by Dr Henryk Rosmarin and Dr Izrael Münzer. ${ }^{8}$

In 1916, Dr Emil Parnas, an advocate of assimilation of Jews, was appointed by the administrative authorities as a commissioner of the Jewish community in Lviv. He was one of the leading figures in the Leopolis B'nei B'rith Humanitarian Society. He was also a member of many other Jewish organizations. He devoted much of his attention to health and hygiene, and after World War I he actively participated in organizing the structures of the Association of Health Protection for the Jewish Population. ${ }^{9}$

When considering the composition of the Presidium, it is worth noting at least two other figures, Dr Alexander Hausmann and Dr Tobiasz Askenase, who closely and harmoniously cooperated with each other in the Jewish Rescue Committee but also represented opposing and fighting political circles. Dr Hausmann, like Dr Ringel, was one of the pioneers of the Zionist movement in Galicia. In 1896, he was part of a group who founded the first Zionist academic corporation, called Emunah, ${ }^{10}$ in Lviv. The attorney Dr Askenase, on the other hand, was an ardent advocate of the assimilation of Jews. He was a member of the Lviv City Council, and in 1909 became the vice-president of Lviv, the first Jew to hold this office. In 1914, he was elected a member of the Galician National Parliament. During World War I he took an active part in the fighting as an officer

\footnotetext{
${ }^{6}$ Sprawozdanie 1919: 5; "Z działalności Żyd. Komitetu ratunkowego we Lwowie w czasie od 1 grudnia 1918 do 31 marca 1919,” Nowy Dziennik, 13 May 1919, no. 86: 3; Imiłowska-Duma 2017: 123; Hagen 2018: 177.

${ }^{7}$ Zaporowski 2008: 155.

${ }^{8}$ CDIAL, Fond 505, desc. 1, case 15: 3-4.

9 Parnas Emil 1937: 418.

${ }^{10}$ Laufer Jakub 1937: 926.
} 
of the Austrian Army. He died in 1920, and in 1932, in recognition of his contribution to the city, the Lviv City Council named a street after him: Tobiasza Askenase Street. ${ }^{11}$ Referring to his participation in the Jewish Rescue Committee, Dr Askenase recalled "In these horrible times fate put me in a position, where I was forced to fight not only in defense of the oppressed Jewry, but also in defense of the greatest ideals of humanity." 12

The number of units created to carry out specific tasks was subject to change according to the nature of the current social needs to which the Jewish Rescue Committee devoted its attention. The work of each unit was directed by members of the Presidium and the Executive Department, as well as other people with specific qualifications and predispositions. In the middle of May 1919, six units were actively operating:

1. The First Aid Unit, headed by Prof. Dr Mojżesz Schorr, an eminent historian employed at the University of Lviv

2. The Reconstruction Unit, headed by Dr Abraham Korkis

3. The Housing and Heating Unit, headed by Dr Mojżesz Dogilewski

4. The Child Protection Unit, headed by Dr Ada Reichenstein and Dr Cecilia Klaften

5. The Damage Registration Unit, headed by Dr Tobiasz Askenase

6. The Sanitary Unit, headed by Dr Samuel Meisels. ${ }^{13}$

After determining the extent and scope of the damage caused by the November pogrom, the Damage Registration Unit was dissolved in the second half of 1919. However, as the Jewish Rescue Committee increased the scope of its activities and extended them to other towns in Eastern Galicia, new units were created and the names of some of the existing ones were changed. As a result, at the end of 1919 there were already 12 units:

1. Provisioning Unit

2. Financial Unit

3. Immediate Aid Unit

4. American Gifts Distribution Unit

5. Workers' Unit

6. Clothing Unit

7. Economic Reconstruction Unit

8. Legal Protection Unit

9. Province Unit

10. Intelligentsia Unit

11. Childcare Unit

12. Sanitary Unit. ${ }^{14}$

The creation of the central office took place at the end of January 1919, which was the result of the increasing number of people appealing for the help of the Jewish Rescue Committee during the winter period. The need for a central office also resulted from some people repeatedly and excessively overusing the assistance, reporting directly to the different sections in turn. In order to streamline operations and eliminate such reprehensible practices, all those in need of assistance had to report to the established central

11 Askenase Tobiasz Stefan 1937: 470, 472.

12 Ibid.: 471.

13 "Z działalności Żyd. Komitetu ratunkowego we Lwowie w czasie od 1 grudnia 1918 do 31 marca 1919," Nowy Dziennik, 13 May 1919, no. 86: 3.

14 CDIAL, Fond 505, desc. 1, case 15: 8 and verte. 
office. There they were registered and the legitimacy of the specific assistance they had applied for was assessed. ${ }^{15}$

\section{Reactions of Jewish circles to the Committee's appeals for help}

As soon as the news of the pogrom and its disastrous consequences spread, Jewish circles on both Polish and international soil immediately sprang to action to help out. Fundraisers for the victims were organized in villages, most notably in the Galicia region. In Krakow, the editorial office of the Zionist magazine Nowy Dziennik coordinated a fundraiser for the victims of the Lviv pogrom. ${ }^{16}$

The Jewish Rescue Committee very much appreciated the importance of Jewish communities helping the victims of the pogrom. At the same time, however, the Committee was aware that this aid was temporary and insufficient to rebuild the destroyed homes and administrative buildings, or to provide the victims with an opportunity to earn a living, employment lost as a result of the robberies and destruction of many shops and craft workshops. The Committee understood that the affected Jewish population required aid from the Polish state authorities. The Committee declared that it would provide the Polish authorities with the necessary information on the scope and form of the much-needed immediate assistance.

Thanks to the generosity of the Jewish community, not only in Lviv and Galicia, but also abroad, the Jewish rescue operation can demonstrate positive results.

However, the damage and the number of victims is so great that the self-help campaign [Jewish circles trying to rebuild on their own] is not enough to equalize the economic damage sustained by the families after the unfortunate events in November. Therefore, what is needed here is a campaign of planned economic recovery for the victims of the pogrom. There is no doubt that the responsibility of initiating such an economic recovery campaign weighs on the Polish government. This obligation was also recognized by the Temporary Council of the City of Lviv, which, on the basis of a motion presented by Dr Aschkenasi [...], decided to refer the matter to the Temporary Ruling Committee.

This economic reconstruction should not encounter any significant obstacles. It is well known that the National Reconstruction Office was set up under the Austrian rule and distributed a significant amount of funds to develop wide scale activities aimed at the reconstruction of the country [...]. It can be assumed that some of the funds still remain within the National Reconstruction Office, which still exists and can thus reliably distribute these funds. [...] The National Reconstruction Office estimated the costs of material damage caused in Lviv starting from 1 November 1918, so that these costs could be recompensed. [...]

We expect that the National Reconstruction Office will recognize the state's obligation to compensate for the damage caused by the November events in the Jewish district and pay close attention to this matter. [...] We are convinced that the National Reconstruction Office could use the assistance of the Jewish Rescue Committee in the registration of damage and in the reconstruction operation, as the Committee is fully aware of the extent of the damage and will undoubtedly support the reconstruction work. ${ }^{17}$

\footnotetext{
15 Ibid.: 20-21.

16 “Na ofiary pogromu we Lwowie," Nowy Dziennik, 2 January 1919, no. 1: 5.

17 “Odbudowa dzielnicy żydowskiej," Chwila, 30 January 1919, no. 17: 1.
} 
The Lviv pogrom of Jews had a huge impact on the international arena, casting Poland in a negative light. ${ }^{18}$ The pogrom became the subject of many comments in the press, and a subject of interest to the governments of some countries and international Jewish organizations. The US Government sent a special commission chaired by Henry Morgenthau to investigate the course and consequences of the pogrom. ${ }^{19}$ Throughout this time, fundraisers to support the pogrom's victims were regularly held in the USA. On 7 June 1919, the Lviv-based daily newspaper Chwila informed that the Jewish Rescue Committee had received information a week before that shipments of clothes collected by American Jews would be coming to Lviv. At the same time, it was mentioned that this clothing would be distributed to those in need, both Jews and Christians. ${ }^{20}$

\section{Assistance given to the victims in the first months after the pogrom}

After its proper establishment, the Jewish Rescue Committee's primary concern became providing immediate aid. The Committee immediately distributed collected money to those in need. People started to receive financial aid and necessary food supplies, mainly through the distribution of free meals in specially created kitchen houses. Assistance was provided in the form of clothing, footwear and underwear. For those whose houses or flats were burned down or completely demolished, the Committee found suitable rooms for temporary residence. Children and youths were provided with care, both orphans who had lost their parents as well as children and youths who remained homeless. Subsequently, the Committee began to find ways to create favorable conditions so that the victims of the pogrom could earn a living. ${ }^{21}$

The Housing and Heating Unit (also referred to as the Accommodation Unit) in the early days after the pogrom focused on finding places for the arson survivors to live. As a result, the 30 families most affected by the pogrom were placed in other families' houses and in private apartments, where they were cared for. The remaining 337 arson survivors were located in five places:

1. in the house at 28 Kopernika Street (61 people in 10 rooms)

2 . in the house at 9 Piekarska Street ( 90 people in 20 rooms)

3 . at the Belwedere Hotel (41 people in 10 rooms)

4. at the Stadtmüller Hotel (24 people in 10 rooms)

5. at Piramovich School, designated for this purpose by the Lviv City Hall (127 people).

Houses and places in hotels for the homeless were provided free of charge by Ignacy Jaeger, Zygmunt Bardach, Franciszek Moszkowicz, and a man with the surname of Turteltaub. In addition to the arson survivors, these houses and hotels housed six Jewish refugees from the Czech Republic, evacuated to Lviv in 1918. They could not return to their

\footnotetext{
18 Klimecki 2000: 128.

19 The subject matter of international reactions to the pogroms in Lviv and other towns in the Galicia region has already been covered by, but not only: Radzik 1988: 27-41; Hagen 2018: 173-176, $185-193$.

20 "Dokumenty chwili," Chwila, 7 June 1919, no. 143: 3.

21 “Odbudowa dzielnicy żydowskiej,” Chwila, 30 January 1919, no. 17: 1.
} 
homes because of the ongoing Polish-Ukrainian conflict. The houses were equipped with beds, mattresses, blankets, tables and wardrobes. Individuals also received the necessary underwear, clothing and footwear. In order to provide food, a separate kitchen was initially set up in each of the places where they were accommodated. Afterwards, food was delivered to all accommodation facilities from the kitchen of the Jewish Rescue Committee, located in Jad Charuzim Restaurant. All homeless people were provided with medical care and children were also provided with help from the Childcare Unit. In addition, the Housing and Heating Unit was responsible for providing the victims of the November pogrom with the necessary fuel. ${ }^{22}$

One result of the pogrom was a relatively large number of wounded people requiring medical attention. Some of them, including children, needed immediate hospitalization or ambulatory care. Medical care for the slightly wounded victims was provided in their homes. In order to meet the needs of the numerous victims and provide them with the necessary medical care, the Sanitary Unit was established on 2 December 1918. Almost all Jewish doctors in Lviv and auxiliary medical personnel - nurses both female and male, etc. - took part in the activities undertaken by the Sanitary Unit. Fifty-two doctors, 25 people from auxiliary medical personnel and four scouts joined the work of the Sanitary Unit.

Those who required hospitalization and ambulatory care were taken to the second wing of the Lazarus Jewish Hospital. An ambulatory clinic was opened for them as well. In addition, the hospital provided ten permanent beds for children under the age of six. After the creation of the Sanitary Unit, so-called sanitary columns comprised of people with medical training were immediately organized. These groups had been allocated to the specific streets of the city and buildings affected by the pogrom. Their task was to successively reach the homes inhabited by the victims of the pogrom. Where medical assistance was deemed necessary, it was provided on the spot by a doctor, who provided follow-up care on following days as well. However, in the case of more severe wounds or deteriorating health, the doctor could decide to transport such a person to the Jewish Hospital. The transportation was taken care of by the Jewish scouts.

The Sanitary Unit provided constant medical care for the people in the above-mentioned houses and hotels where arson survivors were placed, as well as for those in Jewish shelters. The children were also placed there: orphans who had lost their parents during the pogrom, and children whose parents, due to their health condition or financial situation in which they found themselves as a result of the pogrom, could not take care of them. Initially, several doctors who supervised children's health came to the Jewish shelters two to three times a week. A separate doctor was later appointed for each of the Jewish shelters. The shelters were also provided with permanent dental care.

Thanks to the actions taken by the Sanitary Unit, poor patients could acquire medicine prescribed by the doctors free of charge. The funds were distributed to the poor who needed to buy prostheses, glasses or hernia bandages. The sick were informed of the need to abide by the specific hygiene requirements. Despite enormous difficulties, such as lack of water and fuel, 5,836 items of clothing were washed in the Jewish hospital's laundry room for the pogrom victims. Efforts were made to prevent the spread of an

${ }^{22}$ CDIAL, Fond 505, desc. 1, case 15: 16-17, 36-37. 
epidemic, while those who suffered from epidemic typhus were taken care of. Thanks to the constant medical supervision of the houses and hotels designated for arson survivors, either by doctors or nurses depending on the residents' needs, a case of epidemic typhus was quickly discovered in one of the houses. The infected person was quickly attended to and the disease was prevented from spreading to the other residents of the house. ${ }^{23}$

To attempt to evaluate the overall efforts of the Jewish Rescue Committee, it is worth taking a closer look at the report of its activities in the four-month period from 1 December 1918 to 31 March 1919, in which the Committee focused on determining the size of the pogrom, collecting funds, and providing assistance to the victims.

The income of the Jewish Rescue Committee, 1 December 1918 to 31 March 1919:

- in December 1,026,163 Kr

- in January $852,586 \mathrm{Kr}$

- in February $215,821 \mathrm{Kr}$

- in March 866,110 Kr

In total: 2,960,680 Kr

The expenses of the Jewish Rescue Committee in the period of 1 December 1918 to 31 March 1919:

- in December 793,598 Kr

- in January 658,137 Kr

- in February 400,432 Kr

- in March 701,878 Kr

In total: $2,554,045 \mathrm{Kr}$

Sources of income of the Jewish Rescue Committee between 1 December 1918 and 31 March 1919 (15,000 Kr or more):

- The Jewish Committee in Stockholm 100,000 Kr

- Israeli Religious Community in Krakow 15,000 Kr

- B'nei B'rith Humanitarian Society in Krakow 16,000 Kr

- Central Security Committee in Warsaw 250,000 Kr

- Moment Journal editorial office 335,000 Kr

- Silom Emunah Israel in Warsaw 150,000 Kr

- Lviv branch offices of Viennese banks 100,000 Kr

- Jewish Community in Kielce 25,000 Kr

- Jewish Community in Chelm 28,000 Kr

- Jewish Committee in Lodz 105,000 Kr

- Jewish National Council in Krakow 200,000 Kr

- Zionist Organization in Warsaw 100,000 Kr

It should be added that in addition to what is on the list, about $1,000,000 \mathrm{Kr}$ were donated by Lviv Jews. All in all, during the analyzed period, when organizing help for the victims was indispensable and required a great effort, the Jewish Rescue Committee managed to collect a sum of roughly 4 million $\mathrm{Kr}$. On the other hand, the expenses amounted to 2.5 million $\mathrm{Kr}$.

The largest amount of funds was raised in December 1918, as a result of the immediate and spontaneous reaction of the Jewish communities to the tragedy that occurred in

${ }^{23}$ Ibid.: 23-24. 
Lviv at the end of November 1918. In the following months, however, the victims were not forgotten, as evidenced by the relatively large sums collected by the Jewish Rescue Committee. Large sums were donated by private donors, but also by Jewish communities and organizations, mainly Zionist, from Galicia; from the former Russian partition, mainly from those in Warsaw and Lodz, where the two largest concentrations of Jews in Poland lived; and from abroad. It is also worth noting that the Lviv branches of Viennese banks were among the donors.

As was the case with the largest influx of income, the Jewish Rescue Committee spent the most funds in December 1918, which resulted from the need to provide immediate assistance to a relatively large group of people who required medical care and the securing of their means of livelihood. Victims of the pogrom required significant assistance in the following months as well, as evidenced by the amounts spent, especially in January and March.

During the analyzed period, from the beginning of December 1918 to the end of March 1919, the Immediate Aid Unit provided assistance to 3,200 families in a total amount of 960,156 Kr. The Economic Reconstruction Unit provided financial support to 100 merchants and 46 craftsmen and led to the establishment of a cooperative society of milliners and tailors. The Economic Reconstruction Unit spent a total of 161,350 Kr. The Housing and Heating Unit provided 772.8 cubic meters of coal and coke and 218.25 cubic meters of firewood to the victims. The Childcare Unit placed a total of 507 children in orphanages and child protection homes, both orphans whose parents died in the pogrom and children whose parents were wounded in the pogrom and could not take care of them. The Damage Registration Unit, which conducted hearings on the course and effects of the pogrom, collected 4,820 questionnaires and 315 protocols. This work was carried out by 105 people in just two months. ${ }^{24}$

\section{Estimates of the number of casualties and wounded and the extent of material damage}

Due to the importance of the findings of the Damage Registration Unit, the gathered data requires more in-depth discussion and analysis. The Jewish Rescue Committee investigated the consequences of the pogrom and at the end of January 1919 published some of its findings, based on the testimonies of eyewitnesses and victims, in the Lviv daily newspaper Chwila. ${ }^{25}$ The published information concurred to a large extent with the findings of the report published at a later date. This detailed statistical report was compiled on the basis of 3,620 questionnaires containing information on the reported damage caused by the pogroms of 22 and 23 November 1918.

24 “Z działalności Żyd. Komitetu Ratunkowego we Lwowie w czasie od 1 grudnia 1918 do 31 marca 1919," Nowy Dziennik, 13 May 1919, no. 86: 3.

25 "Prawda o pogromach lwowskich," Chwila, 29 January 1919, no. 16: 1. 
Casualties sorted by profession:
a) merchants.
b) craftsmen
c) without permanent occupation ...
d) liberal professions
e) of unknown profession
In total

Wounded sorted by profession:
a) merchants.
104
b) craftsmen
c) workers
d) commercial assistants
e) commercial agents
f) officials
g) private officials
h) liberal professions
i) peddlers
j) others and children
In total

The findings of the Jewish Rescue Committee left no doubt about the enormous scale of the tragedy that was the November pogrom - confirming the large number of casualties and wounded. It was established that 73 people were killed and 443 were injured, which testifies to the brutality of the pogrom. Among those killed, merchants constituted $49.3 \%$, people without a permanent occupation (including women running households, the elderly and children) constituted $30.2 \%$, craftsmen constituted $15.1 \%$, liberal professions constituted $2.7 \%$, and people of unknown profession also constituted $2.7 \%$. However, the largest group among the wounded, $61.2 \%$ of the total, consisted of people running their own private businesses, of no particular profession, and unemployed people: women running households, old people, children, and sick and disabled people. Merchants made up a relatively large percentage of the wounded, accounting for $23.5 \%$ of the total. Craftsmen, at $5.9 \%$ of the total number of the wounded, took third place. The vast majority of the fatalities and wounded were men, who tried to prevent the robberies and destruction from happening. ${ }^{27}$

The scale of the damage and robberies is evidenced by the data contained in Tables 1-6.

26 CDIAL, Fond 505, desc. 1, case 23: 139.

${ }^{27}$ Ibid. Taking into account that the Jewish Rescue Committee had been in the best position to gather information about the full extent of the pogrom, its findings have to be taken at face value as the most reliable. The information about the 73 victims of the pogrom was relayed to the public in January 1919, also in the brochure: Prawda o pogromie lwowskim napisat Bezstronny, Warszawa 1919: 23. The widely known and frequently cited historical publication Bendow 1919: 97 states that there were 72 victims of the pogrom of November 22-23, 1918. However, the report from the Delegation of the Ministry of Foreign Relations about the Antisemitic Manifestations in Lviv claims "There were at least 150 murdered and burned." Tomaszewski 1984: 284. 
Table 1. Estimated value of material damage based on its type (in $\mathrm{Kr}$ )

\begin{tabular}{|l|c|c|r|r|}
\hline \multicolumn{1}{|c|}{ Material loss } & Robberies & Arson & Destruction & In total \\
\hline Cash & $10,869,527$ & 303,170 & 100 & $11,172,797$ \\
\hline Valuables & $6,109,270$ & 299,410 & 34,300 & $6,442,980$ \\
\hline Furniture & - & $2,318,830$ & $1,763,106$ & $4,082,036$ \\
\hline $\begin{array}{l}\text { Bedding and } \\
\text { underwear }\end{array}$ & $15,146,632$ & $1,166,628$ & 108,083 & $16,421,343$ \\
\hline Dresses & - & $1,922,980$ & 190,505 & $2,113,485$ \\
\hline Merchandise & $49,790,143$ & $4,339,817$ & 940,490 & $55,070,450$ \\
\hline Workshops & - & 162,550 & 929,900 & $1,092,450$ \\
\hline Homes & - & $5,219,300$ & $1,371,998$ & $6,591,298$ \\
\hline Total & $\mathbf{8 1 , 9 1 5 , 5 7 2}$ & $\mathbf{1 5 , 7 3 2 , 7 8 5}$ & $\mathbf{5 , 3 3 8 , 4 8 2}$ & $\mathbf{1 0 2 , 9 8 6 , 8 3 9}$ \\
\hline
\end{tabular}

Source: CDIAL, Fond 505, desc. 1, case 23: 140.

One consequence of the November Lviv pogrom was the enormous material damages. According to the findings of the Jewish Rescue Committee, the total material damage was close to 103 million $\mathrm{Kr}$. As can be seen in Table 1, the greatest damage was caused by robbery, which accounted for as much as $79.5 \%$ of the total material damage. The above data may indicate the that the intention of the perpetrators of the pogrom was to commit robberies. On the other hand, damage from arson accounted for $15.3 \%$, and from destruction of property for $5.2 \%$ of the total material damage.

Robbers focused on everything of value that could be carried out in their hands. They robbed houses, shops, warehouses and even synagogues and houses of prayer. Some of the more "entrepreneurial" robbers used trolleys and other means of transport, such as cars, for this purpose. As a result, the highest value of the various stolen goods was taken from shops and warehouses. Bedding and underwear were also of large interest to the robbers, as were cash and valuables, which were very often extorted by force from the victims. $^{28}$

Table 2. The number of robbed families according to the family head's profession and the amount of material damage

\begin{tabular}{|l|c|c|l|c|c|c|c|}
\hline $\begin{array}{l}\text { Family } \\
\text { head's pro- } \\
\text { fession }\end{array}$ & $\begin{array}{l}\mathbf{1 - 5 0 0} \\
\mathbf{K r}\end{array}$ & $\begin{array}{l}\mathbf{5 0 0 - 1 , 0 0 0} \\
\mathbf{K r}\end{array}$ & $\begin{array}{l}\mathbf{1 , 0 0 0}- \\
\mathbf{2 , 5 0 0} \mathbf{~ K r}\end{array}$ & $\begin{array}{l}\mathbf{2 , 5 0 0 -} \\
\mathbf{1 0 , 0 0 0} \mathbf{~ K r}\end{array}$ & $\begin{array}{l}\mathbf{1 0 , 0 0 0}- \\
\mathbf{2 5 , 0 0 0} \mathbf{~ K r}\end{array}$ & $\begin{array}{l}\mathbf{2 5 , 0 0 0 -} \\
\mathbf{5 0 , 0 0 0} \mathbf{~ K r}\end{array}$ & $\begin{array}{l}\text { over } \\
\mathbf{5 0 , 0 0 0} \mathbf{~ K r}\end{array}$ \\
\hline Lawyer & - & 3 & 3 & 5 & 4 & 1 & 5 \\
\hline Engineer & - & 1 & 1 & 1 & - & - & - \\
\hline Doctor & - & 1 & 1 & 5 & 1 & 1 & 2 \\
\hline State official & 2 & 3 & 2 & 13 & 2 & 4 & 5 \\
\hline Peddler & 1 & 2 & 2 & 3 & - & - & 1 \\
\hline Craftsman & 67 & 83 & 123 & 204 & 82 & 38 & 16 \\
\hline
\end{tabular}

${ }^{28}$ See: Mick 2016: 173. 


\begin{tabular}{|l|c|c|c|c|c|c|c|}
\hline $\begin{array}{l}\text { Private of- } \\
\text { ficial }\end{array}$ & 40 & 37 & 52 & 117 & 32 & 27 & 7 \\
\hline Merchant & 92 & 221 & 303 & 398 & 473 & 439 & 401 \\
\hline Other & 33 & 55 & 46 & 78 & 29 & 26 & 11 \\
\hline Total & $\mathbf{2 3 5}$ & $\mathbf{4 0 6}$ & $\mathbf{5 2 3}$ & $\mathbf{8 2 4}$ & $\mathbf{6 2 3}$ & $\mathbf{5 4 6}$ & $\mathbf{4 5 3}$ \\
\hline
\end{tabular}

Source: CDIAL, Fond 505, desc. 1, case 23: 140.

Table 3. The amount of material damage of robbed families in their workplaces and homes (in $\mathrm{Kr}$ )

\begin{tabular}{|l|c|c|c|c|}
\hline $\begin{array}{c}\text { Family head's } \\
\text { profession }\end{array}$ & $\begin{array}{c}\text { Number of } \\
\text { robbed families }\end{array}$ & $\begin{array}{c}\text { Monetary } \\
\text { amount of dam- } \\
\text { age in merchan- } \\
\text { dise or other } \\
\text { damage in the } \\
\text { workplace }\end{array}$ & $\begin{array}{c}\text { Monetary } \\
\text { amount of dam- } \\
\text { age caused at } \\
\text { home }\end{array}$ & $\begin{array}{c}\text { Total monetary } \\
\text { amount of dam- } \\
\text { age }\end{array}$ \\
\hline Lawyer & 21 & 30,000 & 850,331 & 880,331 \\
\hline Engineer & 3 & - & 24,000 & 24,000 \\
\hline Doctor & 11 & - & 549,705 & 549,705 \\
\hline State official & 31 & - & 757,232 & 757,232 \\
\hline Peddler & 9 & 7,000 & 94,830 & 101,830 \\
\hline Craftsman & 312 & $1,719,203$ & $4,021,741$ & $5,740,944$ \\
\hline Private official & 2,337 & - & $2,766,575$ & $2,766,575$ \\
\hline Merchant & 283 & 197,860 & $3,456,552$ & $3,654,412$ \\
\hline Other & $\mathbf{3 , 6 2 0}$ & $\mathbf{5 5 , 0 6 9 , 4 6 0}$ & $\mathbf{4 7 , 9 1 7 , 3 7 9}$ & $\mathbf{1 0 2 , 9 8 6 , 8 3 9}$ \\
\hline Total & & & &
\end{tabular}

Source: CDIAL, Fond 505, desc. 1, case 23: 141.

Table 4. The number of victims based on family head's profession

\begin{tabular}{|l|c|c|}
\hline \multicolumn{1}{|c|}{ Family head's profession } & Number of families & Number of people \\
\hline Lawyer & 21 & 36 \\
\hline Engineer & 3 & 21 \\
\hline Doctor & 11 & 34 \\
\hline State official & 31 & 106 \\
\hline Peddler & 9 & 39 \\
\hline Craftsman & 613 & 2,484 \\
\hline Private official & 312 & 1,104 \\
\hline Merchant & 2,337 & 8,694 \\
\hline Other & 283 & 857 \\
\hline Total & $\mathbf{3 , 6 2 0}$ & $\mathbf{1 3 , 3 7 5}$ \\
\hline
\end{tabular}

Source: CDIAL, Fond 505, desc. 1, case 23: 141. 
According to the data in Table 2, the families of merchants - shopkeepers, wholesalers or stall owners - who earned their living from trade suffered the most material damage from robbery. Second place in terms of the amount of damage suffered was taken by families supporting themselves from craft businesses.

The data in Table 3 indicates another criterion in the assessment of the extent of the robberies, that of location. As already mentioned, the robberies were carried out in houses as well as in other places, mainly where there were desirable goods that could be easily taken. By comparing these two areas of robbery in terms of the value of stolen goods, it can be stated that robberies committed outside houses accounted for $53.5 \%$ of the total, while those from houses accounted for $46.5 \%$ of the total.

As a result of the robberies, as shown in Table 4, exactly 13,375 people were injured, out of which as much as $65.0 \%$ were from families dependent on trade. The percentage of people from craftsmen's families was also high, amounting to $18.6 \%$. Moreover, a relatively large group of victims came from families of private officials employed in private enterprises, as they constituted $8.3 \%$.

Table 5. Robbed families based on number of rooms in the house

\begin{tabular}{|l|r|r|r|r|r|r|}
\hline \multirow{2}{*}{$\begin{array}{c}\text { Family } \\
\text { head's pro- } \\
\text { fession }\end{array}$} & \multirow{2}{*}{$\begin{array}{c}\text { Number of } \\
\text { families }\end{array}$} & \multicolumn{5}{|c|}{ Number of rooms } \\
\cline { 3 - 7 } & & $\mathbf{1}$ & $\mathbf{2}$ & $\mathbf{3}$ & $\mathbf{4}$ & $\mathbf{4}$ \\
\hline Lawyer & 21 & 2 & 6 & 7 & 2 & 4 \\
\hline Engineer & 3 & 1 & - & - & 1 & 1 \\
\hline Doctor & 11 & 1 & - & 3 & 3 & 4 \\
\hline State official & 31 & 2 & 14 & 7 & 5 & 3 \\
\hline Peddler & 9 & 1 & 7 & 1 & - & - \\
\hline Craftsman & 613 & 159 & 338 & 89 & 25 & 2 \\
\hline $\begin{array}{l}\text { Private of- } \\
\text { ficial }\end{array}$ & 312 & 85 & 144 & 62 & 18 & 3 \\
\hline Merchant & 2,337 & 455 & 1,047 & 549 & 197 & 89 \\
\hline Other & 283 & 93 & 117 & 49 & 16 & 9 \\
\hline In total: & $\mathbf{3 , 6 2 0}$ & $\mathbf{7 9 9}$ & $\mathbf{1 , 6 7 3}$ & $\mathbf{7 6 7}$ & $\mathbf{2 6 7}$ & $\mathbf{1 1 5}$ \\
\hline
\end{tabular}

Source: CDIAL, Fond 505, desc. 1, case 23: 142.

The housing situation of the robbed families, which may also be an indicator of their wealth, is referred to in Table 5. Taking into account the size of the apartments, it can be concluded that the largest number of robbed families, as much as $46.2 \%$, lived in apartments consisting of two rooms: a kitchen and another room. $22.0 \%$ of the families lived in apartments of only one room, which was at the same time a kitchen, a place to sleep, and often also a place to work, for example a home of a poor tailor. On the other hand, families with apartments of more than four accounted for only $3.2 \%$. This data may indicate that the robberies were most likely to affect moderately poor families, it should be stressed, poor families. 
The scale of the robberies among the poorer stratum of the Jewish population of Lviv is also evidenced by the data in Table 6 , which very clearly indicates that the victims came predominantly from poor, moderately poor, and even extremely poor families with many children, usually four or more.

Table 6. Robbed families based on the number of household members

\begin{tabular}{|l|c|c|c|c|}
\hline \multirow{2}{*}{$\begin{array}{c}\text { Family head's } \\
\text { profession }\end{array}$} & $\begin{array}{c}\text { Number of } \\
\text { families }\end{array}$ & \multicolumn{3}{|c|}{ Number of household members } \\
\cline { 3 - 5 } & 21 & 2 & $\mathbf{3}-\mathbf{2}$ & $\mathbf{3 +}$ \\
\hline Lawyer & 3 & - & 14 & 5 \\
\hline Engineer & 11 & 2 & 1 & 2 \\
\hline Doctor & 31 & 6 & 8 & 5 \\
\hline State official & 9 & 1 & 1 & 7 \\
\hline Peddler & 613 & 124 & 131 & 358 \\
\hline Craftsman & 312 & 50 & 117 & 115 \\
\hline Private official & 2,337 & 535 & 505 & 1,297 \\
\hline Merchant & 283 & 71 & 89 & 123 \\
\hline Other & & & & \\
\hline
\end{tabular}

Source: CDIAL, Fond 505, desc. 1, case 23: 142.

\section{Conclusions}

The November pogrom and its consequences became a subject of interest and comments from Jewish circles throughout the interwar period. The Jewish Rescue Committee also referred to the consequences of the pogrom in its further activities, pointing out the great efforts of the Jewish community, which rushed to the aid of the victims.

The Committee, referring to the enormous mobilization and generosity of Jews in Poland and abroad, emphasized that self-help had been and remained the only way to save the Jewish masses. After expanding its activities to the whole of Eastern Galicia, the Jewish Rescue Committee continued to appeal to the richer circles of the Jewish population for continued generosity in assisting the poor.

For example, an appeal titled "Uwagi na czasie" (Remarks on the times) published in the Lviv journal Chwila at the beginning of December 1921 pointed out that it was also the duty of those who were given help after the November pogrom in 1918 - which enabled them to prosper enough to now be able to help others - to help the Jewish Rescue Committee in its further activities. ${ }^{29}$

29 “Uwagi na czasie," Chwila, 3 December 1921, no. 1030: 4. 
It has to be noted that the pogrom has negatively affected Polish-Jewish relations. ${ }^{30}$ That is because on November $22-23$ the Polish authorities failed to immediately condemn the antisemitic pogroms and robberies. The victims of the pogrom were not defended by the state. As a result, the perpetrators who murdered, stole, plundered and set buildings on fire were not ostracized by the Polish society, and thus felt their actions were justified. ${ }^{31}$

Despite many propagandist actions taken by the Polish authorities of the Second Polish Republic to not call the Lviv pogrom of November 1918 a pogrom, and to minimize the role that Poles and the Polish Army played in it, it is impossible to fully absolve Poles of blame for what happened. ${ }^{32}$ The Polish authorities and the Polish society cannot be excused either, as they left the aid of the victims of the pogrom to the Jewish Rescue Committee. However, all of the issues surrounding this pogrom still require comprehensive study and consideration.

\section{ABBREVIATIONS}

CDIAL - Central State Historical Archives of Ukraine in Lviv

\section{BIBLIOGRAPHY}

\section{Archival sources}

CDIAL

Fond 505, desc. 1, case 15, 23.

\section{Printed sources}

Bendow, J. (1919), Der Lemberger Judenpogrom (November 1918-Jänner 1919), Wien-Brünn.

Chajes, W. (1997), Semper Fidelis. Pamiętnik Polaka wyznania mojżeszowego z lat 1926-1939, Kraków.

Engel, D. (2004), Lwów, November 1918: The Report of the Official Polish Governmental Investigating Commission, Kwartalnik Historii Żydów 3: 387-395.

Prawda o pogromie lwowskim napisat Bezstronny, Warszawa 1919.

Sprawozdanie 1919 - Sprawozdanie Żydowskiego Komitetu dla niesienia pomocy ofiarom rozruchów i rabunków w listopadzie 1918 we Lwowie w skróceniu Żydowski Komitet Ratunkowy (Ż. K. R.) za czas od 25. listopada 1918 do 1. grudnia 1919, Lwów 1919.

Tomaszewski, J. (1984), Lwów. 22 listopada 1918, Przegląd Historyczny 75(2): 279-285.

Urynowicz, M. (2010), Raport Henry'ego Morgenthau: przemoc antyżydowska podczas wojny z Rosją bolszewicką, Biuletyn Instytutu Pamięci Narodowej 11: 70-79.

Zaporowski, Z. (2008), Listy Władysława Sikorskiego do Żydowskiego Komitetu dla Niesienia Pomocy Ofiarom Rozruchów i Rabunków w listopadzie 1918 roku we Lwowie, Res Historica 26: 155-159.

\footnotetext{
${ }^{30}$ See: Chajes 1997: 134-138.

${ }^{31}$ Reder 2011: 42-53.

32 Gauden 2019: passim.
} 


\section{Press}

Chwila 1919, 1921.

Nowy Dziennik 1919.

\section{Secondary literature}

Askenase Tobiasz Stefan (1937), in: H. Stachl (ed.), Almanach żydowski, Lwów: 470-472.

Drexler, I. (1920), Wielki Lwów, Lwów.

Gauden, G. (2019), Lwów kres iluzji. Opowieść o pogromie listopadowym, Kraków.

Hagen, W.W. (2005), The Moral Economy of Popular Violence: The Pogrom in Lwów, November 1918, in: R. Blobaum (ed.), Antisemitism and Its Opponents in Modern Poland, Ithaca: 124-147.

Hagen, W.W. (2018), Anti-Jewish Violence in Poland, 1914-1920, New York.

Imiłowska-Duma, A. (2017), Stosunki polsko-żydowskie we Lwowie w latach 1918-1919 (wybrane zagadnienia), Polonistyczno-Ukrainoznawcze Studia Naukowe 3: 117-134.

Klimecki, M. (2000), Lwów 1918-1919, Warszawa.

Laufer Jakub (1937), in: Almanach i leksykon żydostwa polskiego, vol. 2-3, Lwów: 926.

Markowski, D.K. (2019), Dwa powstania. Bitwa o Lwów 1918, Kraków.

Mick, C. (2016), Lemberg, Lwów, L'viv, 1914-1947. Violence and Ethnicity in a Contested City, Indiana.

Parnas Emil (1937), in: H. Stachl (ed.), Almanach żydowski, Lwów: 418.

Radzik, T. (1988), Stosunki polsko-żydowskie w Stanach Zjednoczonych Ameryki w latach 1918-1921, Lublin.

Reder, E. (2011), Pogrom lwowski 1918. Inicjatorzy, bierni obserwatorzy, podżegacze, in: A. Kawalec, W. Wierzbieniec, and L. Zaszkilniak (eds.), Galicja 1772-1918. Problemy metodologiczne, stan i potrzeby badań, vol. 2, Rzeszów: 38-55.

Wierzbieniec, W. (2000), Ludność żydowska Lwowa w okresie II Rzeczypospolitej, in: J. Basta and G. Zamoyski (eds.), Historia, archiwistyka, ludzie, Warszawa-Rzeszów: 289-317.

Wierzbieniec, W. (2004a), Antyżydowskie rozruchy, in: J. Draus (ed.), Encyklopedia Rzeszowa, Rzeszów: 13-14.

Wierzbieniec, W. (2004b), Zajścia antyżydowskie w Przemyślu pod koniec 1918 r., in: K. Jasiewicz (ed.) Świat niepożegnany. Żydzi na dawnych ziemiach wschodnich Rzeczypospolitej $w$ XVIII-XX wieku, Warszawa: 573-580.

Wierzbieniec, W. (2005a), Dokumenty dotyczące rozruchów antyżydowskich w powiecie kolbuszowskim na początku maja 1919 roku, Prace Historyczno-Archiwalne 15: 199-212.

Wierzbieniec, W. (2005b), Żydzi a konflikt polsko-ukraiński w Przemyślu pod koniec 1918 roku, in: W. Wierzbieniec (ed.), Polska-Europa-Świat XX wieku. Studia i szkice ofiarowane Profesorowi Włodzimierzowi Bonusiakowi w czterdziestolecie Jego pracy twórczej, Rzeszów: 589-612.

Wierzbieniec, W. (2019), Rytmy codzienności i niecodzienne wydarzenia w relacjach polskożydowskich w Tyczynie w okresie międzywojennym, in: M. Zemło (ed.), Małe miasta. Codzienność, Białystok-Głogów Małopolski-Supraśl: 443-464.

Zaporowski, Z. (2018), Ofiary rozruchów i rabunków we Lwowie 22-24 listopada 1918 roku w świetle ustaleń Lwowskiej Dyrekcji Policji, Pamięć i Sprawiedliwość 1(31): 465-472.

Zaporowski, Z. (2019), Wokół wydarzeń we Lwowie 22-24 listopada 1918 roku, Pamięć i Sprawiedliwość 1(33): 270-280. 